\title{
DNA Repair Gene Mutation
}

National Cancer Institute

\section{Source}

National Cancer Institute. DNA Repair Gene Mutation. NCI Thesaurus. Code C131783.

A change in the nucleotide sequence of a gene involved in DNA repair. 